\title{
CEO Tenure, CEO Compensation, Corporate Social and Environmental Performance in China: The Moderating Role of Coastal and Non-coastal Areas
}

\author{
Talat Mehmood Khan ${ }^{1 *}$, Gang Bai', Zeeshan Fareed ${ }^{2}$, Shakir Quresh ${ }^{1}$, Zameer Khalid ${ }^{3}$ \\ and Waheed Ahmed Khan ${ }^{4}$
}

${ }^{1}$ School of Finance, Southwestern University of Finance and Economics, Chengdu, China, ${ }^{2}$ School of Business, Huzhou University, Huzhou, China, ${ }^{3}$ School of Economics and Management, Xinjiang University, Urumqi, China, ${ }^{4}$ Department of Computer Science, COMSATS University Islamabad, Wah Cantt, Pakistan

This study uncovers a new finding on the impact of CEO tenure on corporate social and environmental performance (CS\&EP) in coastal and non-coastal areas of China using fixed-effect panel data regression models. The Two-Stage Least Squares instrumental panel regression is used to validate the veracity of the empirical results. To this end, we extract data from all non-financial Chinese listed firms for the period of 2009 to 2015. By applying the multivariant framework, the findings of the study exhibit a negative and significant effect of CEO tenure on CS\&EP. Moreover, this study shows that firms with head offices in coastal areas of China tend to weaken the negative impact of CEO tenure on CS\&EP, indicating that CS\&EP is more focused in coastal areas of China than noncoastal ones. The findings suggest that the increase in CEOs' CS\&EP in the early years of their service tenure tends to increase their compensation packages. This study is useful for policymakers to link CS\&EP with firm economic practices to attain sustainable development objectives.

Keywords: coastal areas, CEO compensation, CS\&EP, career-concerns, stakeholder

\section{INTRODUCTION}

The extant literature signifies that social activities are performed for investment and signaling purposes (Su et al., 2016). In addition, stakeholder theory indicates that social projects are most likely to be considered as a stable investment to satisfy stakeholder expectations and consequently enhance firm performance (Wood, 1991; Price and Sun, 2017; Hu et al., 2018). In keeping with this argument, it is logical to anticipate that CEOs are more willing to initiate social projects to enhance firm performance. Accordingly, CEOs are more focused on organizing firm earnings during their initial tenures when boards of directors are keener on evaluating their capabilities regarding firm performance (Ali and Zhang, 2015). Moreover, due to the growing recognition of social activities at the firm level, executives are more likely to address social activities to improve their performance evaluations (Callan and Thomas, 2011; Hong et al., 2016; Liu and Zhang, 2017). Therefore, it is necessary to explore the differentiating role of $\mathrm{CEO}$ tenure on corporate social and environmental performance (CS\&EP).

Coastal areas all around the world are attractive zones for both businesses and residences due to their abundant natural resources. Approximately $50 \%$ of the world's population resides 
in coastal areas, which represents about $10 \%$ of the earth's surface (Thia-Eng, 1993). Due to excessive population growth, pollution, over-exploitation of resources, and multiple resourceuse conflicts, social development and environmental issues in coastal zones should be promoted and addressed through corporate social responsibility (Henceforth, CSR). China's coastal areas cover around $18,000 \mathrm{~km}$ and extend across temperate, tropical, and subtropical zones (Cao and Wong, 2007; Qin et al., 2008). In China, about $60 \%$ of the population lives in the 12 coastal provinces. Moreover, around $70 \%$ of the biggest Chinese cities are situated in coastal areas and contribute to more than $55 \%$ of the country's gross domestic product (Wang, 1992). The rapid urbanization, economic development and infrastructure development of China's coastal areas increase their environmental deterioration and lead to ecosystem decline (Xue et al., 2004; Wu et al., 2012). The State Oceanic Authority is the only authority administering China's coastal zones. The terrestrial land in the coastal areas does not fall under the State Oceanic Authority's jurisdiction (Chen and Pearson, 2015). Therefore, the State Council of the People's Republic of China (PRC) has implemented several laws to protect China's coastal regions and enhance its social and environmental activities, such as the Law on the Territorial Sea and the Contiguous Zone (State Council of the PRC, 1992), the Law of the Exclusive Economic Zone and Continental Shelf (State Council of the PRC, 1998), and the Law on the Use and Management of Sea Areas (State Council of the PRC, 2001). In addition, the Chinese government has implemented integrated coastal zone management (ICZM), which is an internationally approved management tactic to address conflicts between economic development, social responsibility, and environmental protection to attain more sustainable coastal zone development (Chen and Pearson, 2015). The PRC's ICZM project in Xiamen started in the mid-1990s and is considered the best example of ICZM execution (Hong and Xue, 2006). The ICZM project has now entered its second phase by accomplishing its required goals and receiving a positive response from the international community.

Approximately $70 \%$ of China's biggest cities are situated in coastal regions, and contribute significantly to the country's GDP (Wang, 1992). Therefore, the Chinese government is more focused on CS\&EP projects in coastal zones. The role of firms in assisting and promoting social projects is much encouraged by the government and public sectors (Elkington, 1994; Laszlo and Cescau, 2017). Furthermore, multinational companies, like Nike, Carrefour, and GE, have urged CSR evaluations of their Chinese supplier firms (Ying et al., 2006). Approximately 8,000 Chinese firms situated in coastal zones have faced such factory evaluations (Ying et al., 2006). Hence, one primary task of Chinese firms is to upgrade their socially responsible competitiveness in the international market. All the pressure from the government, labor trade barriers, and green trade barriers has pushed Chinese firms to be more focused on CS\&EP in coastal zones.

This paper extends the previous line of research by providing evidence of how the impact of CEO tenure on CS\&EP varies in the coastal and non-coastal areas of China. Previous literature has shown a positive association between the CEO and the firm's social performance (Li et al., 2020; Sarfraz et al., 2020b).
Therefore, the variety of CEOs' personality attributes and performance contracts provides a robust explanation for the dissimilarities of an organization's CSR performance (Hambrick and Mason, 1984; Karim et al., 2018; Sarfraz et al., 2020b). CEOs have a strong association with a firm's operational tasks. In most CEOs' early service tenure, monitoring authorities, including government and a firm's board of directors, are indecisive regarding the CEO's capabilities. This leads to career concerns (Holmstrom, 1982; Gibbons and Murphy, 1992). In a wider prospect of cognitive development through moral socialization of CEOs, their ethical motivation varies across their life span (Kohlberg, 1969; Walker and Frimer, 2015). Therefore, executives demonstrating superior execution in their early service tenure ultimately reap greater rewards in their later service period in the form of self-governance, significant future remuneration, and service extensions (Hermalin and Weisbach, 1998). Due to the positive association between social practices and firm performance (Friede et al., 2015), CEOs in their early tenure are more likely to involve themselves in social practices and earnings overstatement to alleviate career concerns (Ali and Zhang, 2015). Therefore, we develop an argument that the increasing trend of CEO tenure tends to decrease the firm's CS\&EP. This is because CEOs address more CS\&EP in the initial period of their service tenure to decrease career concerns, as social projects are considered a stable investment for extended service period (Palmer, 2012; Xiong et al., 2016). In the initial service period, CEOs are most likely to invest in social and environmental projects to reap rewards in their later years of service. To align these arguments, we propose an inverse association between $\mathrm{CEO}$ tenure and CS\&EP. In the same vein, excessive government pressure, labor trade, and green trade barriers have pushed Chinese firms to be more focused on social activities in coastal areas (Ying et al., 2006). Therefore, we hypothesize that the inverse impact of CEO tenure on CS\&EP is weaker in the coastal areas of China.

However, another interesting question remains to be answered: Does the CEO's early service tenure engagement in social and environmental activities increase or decrease their compensation package in the Chinese context? We further extend our line of research to uncover the impact of CS\&EP on CEOs' total compensation. Conventional wisdom proposes that firms should accommodate CEOs' desires to pursue social activities to raise the firm's performance. Following corporate governance and the Global Reporting Initiative, the total compensation of top executives should be aligned with their social practices. For example, in 2013, the combined report of the Sustainable Investment Institutes and the Investor Responsibility Research Center indicated that $43 \%$ of Fortune 500 companies related top executive remuneration to their social activities ${ }^{1}$. However, the existing literature on the relationship between CEO compensation and social practices is inconclusive. On the one side, contradictory to conventional wisdom, researchers have observed that there is an inverse association between social activities and CEO compensation (Coombs and Gilley, 2005;

\footnotetext{
${ }^{1}$ http://www.csrhub.com/blog/2013/05/top-companies-tie-compensationtosustainability.html
} 
Russo and Harrison, 2005), while on the other side, Berrone and Gomez-mejia (2009) have argued that environmental performance enhances CEOs' compensation.

During a CEO's early service tenure, the board of directors is more concerned with the CEO's performance, which ultimately increases the CEO's career-related concerns. Therefore, CEOs are more likely to address social practices to avoid the risk of dismissal and loss of pay (Oh et al., 2014). Extant research has shown that an increase in a firm's social practices may increase its shareholders' wealth (Fernández-Guadaño and Sarria-Pedroza, 2018). In the context of the present research, we propose that an increase in a CEO's social and environmental practices is associated with an increase in shareholder wealth. The CEO's CS\&EP is positively correlated with their compensation package due to their social engagements (value-added hypothesis). Taken together, we propose that a CEO's early-tenure CS\&EP has a positive impact on their total compensation.

This study contributes significantly to the existing literature. To the best of our knowledge, this study is the first to comprehensively discern the link between CS\&EP and CEO tenure in the coastal and non-coastal areas of China. Secondly, this study finds evidence that CEOs' commitment to social and environmental goals is stronger in their initial service period than in their later service years. Third, we find that CEOs' initial tenure investment in CS\&EP could increase their total compensation. The rest of the study is arranged as follows. In section "Related Literature and hypothesis development," we review the literature and present the hypothesis development. Section "Research Design" provides the model specification and sample size. Section "Main Results and Analyses" explains the results of the study and offers concluding remarks.

\section{RELATED LITERATURE AND HYPOTHESIS DEVELOPMENT}

\section{Signaling Theory Effect}

Signaling theory is based upon the assumption of information asymmetry and argues that a firm's financial decisions work as a signal directed by the firm's management to the stakeholders to address these asymmetries. In the present study, we expect CEO tenure to have an inverse impact on CS\&EP for two reasons. First, in the initial service tenure, executives have more opportunities to engage in CS\&EP to signal their ability to mitigate career-related concerns. In the early service period, the market is not confident in the newly hired CEO's abilities (Holmstrom, 1982; Gibbons and Murphy, 1992). The CEO's skills could be assessed based on financial and non-financial achievements (Chiu and Sharfman, 2016). Their unsatisfactory performance results in dismissal, low pay, and fewer perks (Deckop et al., 2006; Chiu and Sharfman, 2016). In the initial service period, CEOs are more interested in signaling their capabilities to reduce career-related concerns (Fama, 1980; Hermalin and Weisbach, 1998), while monitoring authorities consider financial and non-financial achievements as the benchmarks with which to assess their performance (Ali and Zhang, 2015; Hong et al., 2016). Moreover, Friede et al. (2015) recently reviewed the literature, finding that, in 2,200 studies, there was a positive association between a firm's social and financial performance. Social performance is also an important indicator highlighting the capabilities of CEOs to reduce career risks, rather than conflicting with firm earnings (Ali and Zhang, 2015). Therefore, we propose that in the initial tenure of service, executives are more motivated to engage in social activities to alleviate career risks. Since social performance has been shown to be an important measure with which to assess CEO performance (Benabou and Tirole, 2010; Borghesi et al., 2014; Lys et al., 2015; Hong et al., 2016), we link it with CEOs' career-related concerns.

Secondly, we postulate that an adverse effect of CEO tenure on CS\&EP is because of the CEO's career horizon. A newly appointed CEO has a longer anticipated career than those who are near retirement (Khan et al., 2020b). Therefore, CEOs in their early tenure are more likely to invest in social and environmental projects, and this leads to them being rewarded in their later service tenure by enhancing future firm value. This is in keeping with Pan et al. (2016), who suggest that a CEO's investment activities are significantly higher in their early service tenure. However, social practices also foster long-lasting advantages for firms. Therefore, we posit that CEOs are more focused on CS\&EP in their initial service years than they are in their final service years. Taken together, we propose that CEO tenure has a negative effect on CS\&EP. Based on these justifications, we propose the following hypothesis.

H1. CEO tenure has a negative and significant impact on CS\&EP.

\section{Coastal Areas Effect}

In this section, we strive to elaborate on how the effect of CEO tenure on CS\&EP varies between coastal and non-coastal areas of China. In a recent study, Li et al. (2019) observed that increased social practices are taking place in the highly developed areas of China's coastal zones. In addition, using data envelopment analysis, Wang et al. (2016) documented that the CSR efficiency score has a stable pattern in most provinces and in cities situated in the coastal areas of China. Our argument that social and environmental practices are attracting more attention in the coastal zones of China is based on the following.

First, coastal regions in China are more developed, and these populated areas contribute more than 55\% of the country's GDP (Wang, 1992). There are some social and environmental risks created by fast economic development that needed to be addressed as a matter of priority (Wang et al., 2016). Therefore, on 1st January 2006, the Chinese government-being a key stakeholder-implemented a new law forcing firms to be socially responsible in their operations (National People's Congress [NPC], 2005). As per article-five of National People's Congress law, companies are bound to engage in social practices and manifest their business ethics and social morality in a real way. Moreover, ICZM is overseen by the Chinese government. This is an internationally accepted management tool used to resolve conflicts regarding economic development, social responsibility, and pollution to protect the ongoing development of the country's coastal zones (Chen and Pearson, 2015). Taken altogether, we postulate that CS\&EP is more focused on the 
coastal areas of China, and increase in CEO tenure may increase CS\&EP because CEOs' career-related concerns remain constant throughout their careers due to excessive government pressure (Liu and Zhang, 2017).

Second, social performance is the basic requirement for Chinese firms to be able to compete internationally. Therefore, multinational corporations, like Carrefour, Nike, and GE, are strictly monitoring the CSR evaluation processes of their Chinese supplier firms (Ying et al., 2006), and almost 8,000 Chinese companies situated in the coastal zones are facing factory evaluations related to their social activities. Hence, one of the main tasks of Chinese firms is to upgrade their socially responsible competitiveness in the international market. Moreover, labor trade barriers and green trade barriers have pushed Chinese firms to be more focused on social activities in coastal zones. Therefore, we postulate that the negative relationship between CEO tenure and CS\&EP is weaker in the coastal areas of China (Figure 1), which leads to the following hypothesis:

H2. The negative effect of CEO tenure on CS\&EP is moderated by coastal areas. Specifically, this negative association becomes weaker in the firms with headquarters situated in the coastal areas of China.

\section{Value-Added Hypothesis}

We argue that a CEO's early service tenure engagement in CS\&EP activities increases their compensation by mitigating careerrelated concerns. Extant research has shown that the CEO's early service years' engagement in social activities could be a helpful tool with which to reduce career-related concerns (Oh et al., 2014) and ultimately increase the CEO's compensation (Berrone and Gomez-mejia, 2009). However, other studies have shown that the increase in social activities may reduce the CEO's compensation (Coombs and Gilley, 2005; Russo and Harrison, 2005), meaning that the results are mixed. Therefore, we have extended this line of research in an emerging market to address this underlying issue.

The increase in social involvement increases shareholder wealth because the improved social investment is correlated with a high-quality workforce (Greening and Turban, 2000), increases demand for a firm's product in the market (Navarro, 1988), leads to stronger customer loyalty to a firm's products (Sen and Bhattacharya, 2001), and creates more convenience to attract quality resources (Cochran and Wood, 1984). On the other side, existing studies show that social practices are more likely to enhance a firm's non-financial performance through better product quality (Johnson and Greening, 1999) and operational efficiencies (Sharma and Vredenburg, 1998). These studies align with stakeholder wealth maximization theory (Cornell and Shapiro, 1987; Hill and Jones, 1992), which suggests that firms act according to the contract between stakeholders (i.e., customers, employees, and suppliers) and shareholders. Each set of stakeholders provides firms with significant resources against the terms mentioned in the direct contract (i.e., product guarantee and wages contract) or indicated in indirect contracts (i.e., ongoing services to customers and promising job security to employees). If an increase in social investment is associated with stakeholders' interests (i.e., customers, employees, and suppliers), these stakeholders will work to support the betterment of the firm's operations, which ultimately enhances the shareholders' wealth. Social practices are considered an important indicator to enhance shareholders' wealth. Focusing more on securing the stakeholders' interests ultimately makes them more inclined to support the firm's operations, which results in an increase in the shareholders' wealth. In this line of research, since in the initial service tenure of a CEO the gradual increase in social and environmental investment is associated with the betterment of the firm's shareholders' wealth, we anticipate that the CEO would be rewarded for their commitment to enhancing CS\&EP, which would consequently reduce their career-related concerns. Therefore, we posit that there is a positive relationship between the CEO's initial service CS\&EP and total compensation.

H3. The increase in a CEO's early service tenure CS\&EP enhances their total compensation.

\section{RESEARCH DESIGN}

\section{Sample Selection}

This study finds an association between CEO tenure and CS\&EP in coastal and non-coastal areas of China. Our sample consists of 3,282 unbalanced observations of non-financial Chinese listed firms from 2009 to 2015. We retrieve our data from China Stock Market and Accounting Research (CSMAR), which incorporates firms' financial and board composition data (Gao et al., 2017). Moreover, CS\&EP data are extracted from the Rankins (RKS) dataset (Shahab et al., 2018; Sial et al., 2018).

\section{Measures}

\section{Corporate Social and Environmental Performance}

Corporate social and environmental performance is a dependent variable in this study. The data are extracted from the RKS dataset available in the "HEXUN" database for Chinese listed firms. RKS is a private firm operating under the guidelines set by the Global Reporting Initiative. The extant literature has used the RKS dataset to conduct CS\&EP research (Marquis and Qian, 2013; Shahab et al., 2018; Sial et al., 2018). Moreover, Marquis and Qian (2013) have implemented some robustness techniques to assure validity of the measures in RKS dataset. The RKS dataset uses three leading indicators in their evaluation process, which are shown in Table 1. Each factor is rated from zero to 100. The total firm rating quality score is measured by incorporating the weighted average of all three indicators from zero to 100 .

\section{CEO Compensation}

We retrieve CEO compensation data from CSMAR. These data are based on the reported sums of CEO pay, stipends, and bonuses, consistent with Conyon and $\mathrm{He}$ (2012).

\section{CEO Tenure}

CEO tenure is the independent variable in this study, which is measured by the total number of years an executive has held the chief executive office (Hu et al., 2015; Chen and Tsang, 2017). 
TABLE 1 | Three indicators from the Rankins (RKS) dataset.

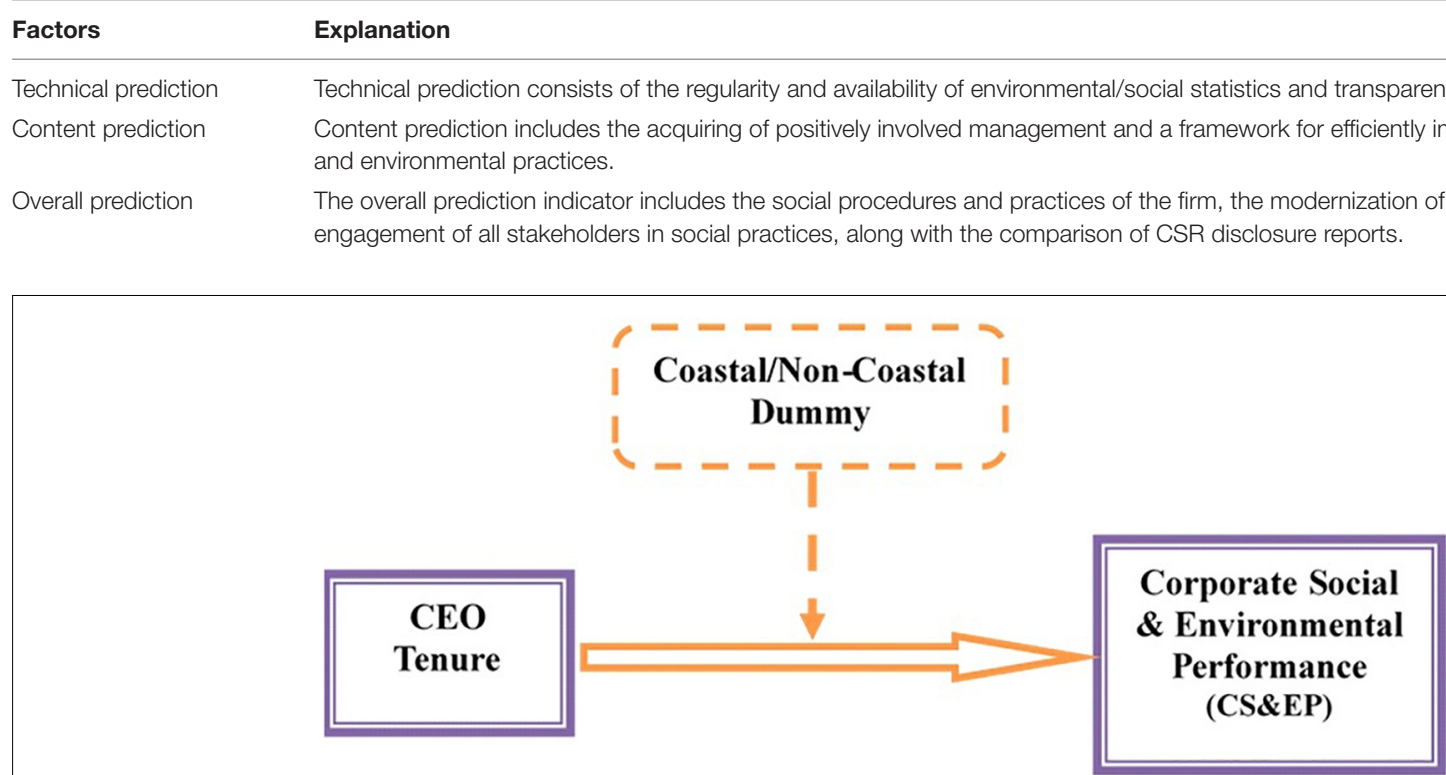

FIGURE 1 | Moderating role of coastal/non-coastal areas.

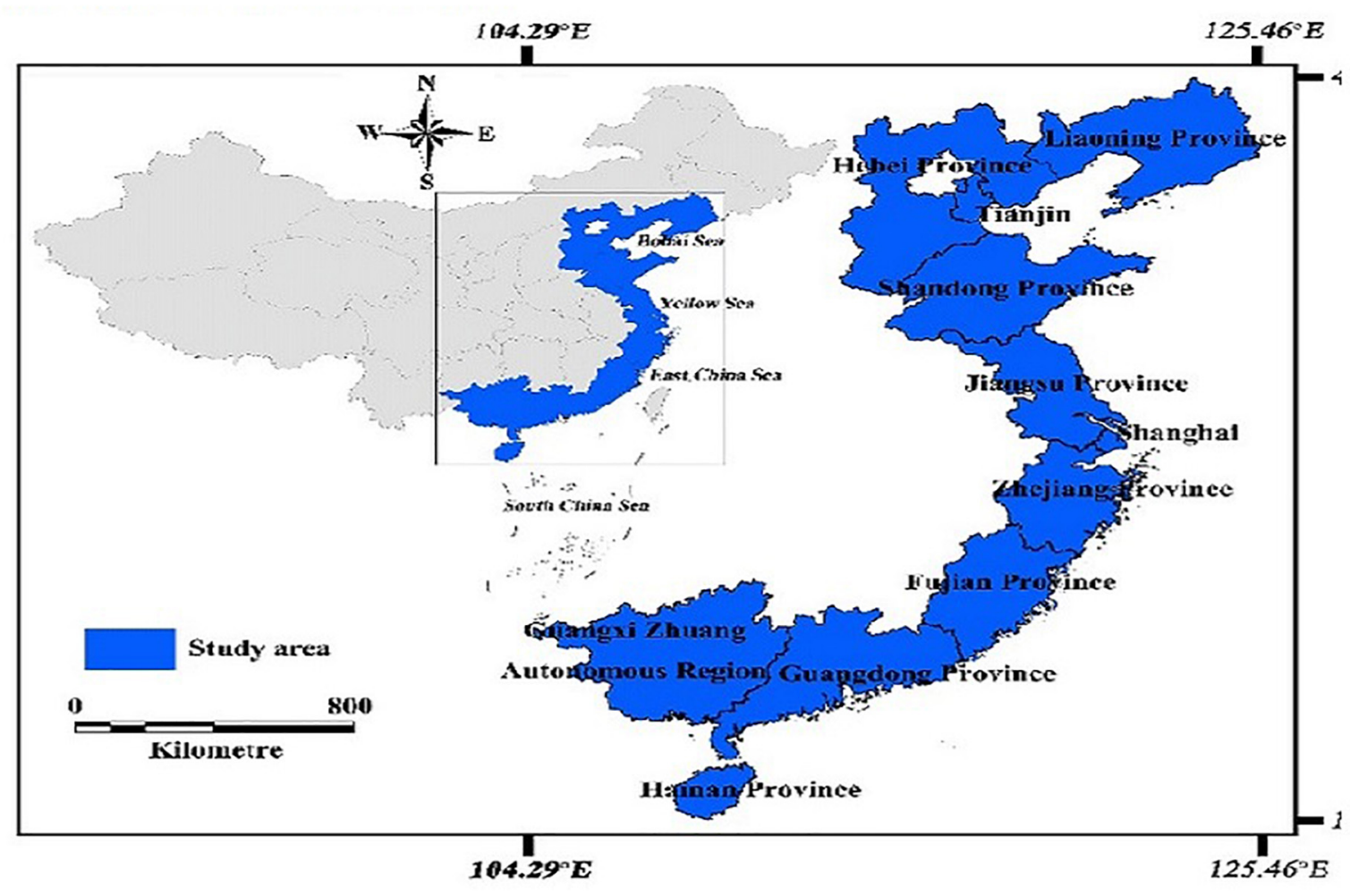

FIGURE 2 | Coastal areas of China.

\section{Coastal Dummy}

We segregate our sample with the help of the Chinese coastal area map provided in Figure 2 (Sun et al., 2015). We use a coastal zone dummy variable which equals one if the firm's headquarters is situated in the coastal region of China and zero if not (Fleisher and Chen, 1997; Purdy and Chang, 2014). 


\section{Model Specification}

We propose the following models for this study.

$$
\begin{gathered}
\text { CS\&EP } \mathrm{E}_{i, t}=\alpha+\beta_{1} \text { CEO TNUR } \text { TNt-1 }_{i, t}+\beta_{2} \\
\text { CEO Level_Controls } i_{i, t-1}+\beta_{3} \\
\text { Firm Level_Controls } s_{i, t-1}+\mu_{i, t} \\
\text { CS\&EP } i, t=\alpha+\beta_{1} \\
\text { CEO TNUR } \times \text { COASTALDMY }{ }_{i, t-1}+\beta_{2} \\
\text { CEO Level_Controls }{ }_{i, t-1}+\beta_{3} \\
\text { Firm Level_Controls } s_{i, t-1}+\mu_{i, t} \\
\text { CEO_COMP } i, t=\alpha+\beta_{1} \\
\text { CS\&EP(Initial service years })_{i}+\beta_{2} \\
\text { ROA(initial service years })_{i}+\beta_{3} \\
\text { CEO Level_Controls } s_{i}+\beta_{4} \\
\end{gathered}
$$

In model 1, CS\&EP is a dependent variable and CEO tenure (CEO TNUR) is taken as an independent variable. To investigate the association between CEO tenure and CS\&EP, we control for a few aspects that have been mentioned in the existing literature. Specifically, we control for CEO age (CEO AG), assuming that younger CEOs have more opportunities to become involved in social activities than older CEOs (Oh et al., 2014; Khan et al., 2020a). We include CEO duality (CEO DLTY) as a control variable and anticipate an inverse impact of CEO duality on social activities, because CEO duality and corporate social reputation have a negative relationship (Lu et al., 2015). CEO gender (CEO GNDR) is the most frequently considered difference in the related research. Still, the findings are diverse. Zhuang et al. (2018) investigated and found that a higher number of female executives decreases the rating standard of the corporation. Moreover, related research shows that a higher percentage of female executives has a positive impact on social performance (Manner, 2010). CEO education (CEO EDUC) has a significant relationship with the firm's social performance (Manner, 2010); therefore, we control for CEO education to examine its impact on CS\&EP.

Some governance control variables are also used. We control the percentage of independent directors observing firm performance. Independent boards are accountable for protecting the shareholders' interests, whereas organizations with an extended number of independent boards more actively execute social practices (Ortas et al., 2017). The extant literature documents a positive and significant association between ownership concentration (OWNR CONCN) and social practices (Wang et al., 2013; Lahouel et al., 2014), while previous literature further evaluates and finds a negative impact of ownership concentration on social practices (Dam and Scholtens, 2013).

We further include several firm-level control variables. We anticipate that older (F. AGE) and larger (F. SIZE) organizations are more likely to be involved in social practices because they have more investment resources (McGuinness et al., 2017; Shahab et al., 2018; Sarfraz et al., 2020a). Therefore, we expect firm

\begin{tabular}{|c|c|c|c|c|c|c|}
\hline & No. of observation & MEAN & SD & Quarter 1 & Median & Quarter 2 \\
\hline CEO TNUR R $_{t-1}$ & 3,251 & 6.022 & 3.626 & 3.000 & 5.000 & 9.000 \\
\hline CEO AG $A_{t-1}$ & 3,251 & 53.348 & 6.395 & 49.000 & 53.000 & 58.000 \\
\hline CEO DLTYt & 3,282 & 0.167 & 0.373 & 0.000 & 0.000 & 0.000 \\
\hline CEO GNDR GN-1 $_{t}$ & 3,251 & 0.967 & 0.178 & 1.000 & 1.000 & 1.000 \\
\hline P. INDBRD $t-1$ & 3,278 & 45.141 & 14.454 & 33.333 & 40.000 & 50.000 \\
\hline F. SIZE $_{t-1}$ & 3,282 & 23.263 & 1.788 & 22.020 & 22.997 & 24.142 \\
\hline F. $A G_{t-1}$ & 3,282 & 16.543 & 5.094 & 13.000 & 16.000 & 20.000 \\
\hline OWNR CONCN $\mathrm{CH}_{t-1}$ & 3,282 & 59.240 & 17.067 & 47.630 & 59.340 & 71.380 \\
\hline $\operatorname{LEVG}_{t-1}$ & 3,282 & 0.519 & 0.213 & 0.361 & 0.532 & 0.675 \\
\hline $\mathrm{ROA}_{t-1}$ & 3,065 & 6.8300 & 6.542 & 3.412 & 5.932 & 9.511 \\
\hline
\end{tabular}
age and firm size to have a positive impact on CS\&EP. In addition, the firms that depend more on leverage ratios are less interested in social projects. The extant research has found that more leveraged firms tend to decrease their corporate social performance (Shahab et al., 2018; Khan et al., 2019). Following this argument, we expect to find an inverse association between a firm's leverage and its CS\&EP.

In model 2, we introduce an interaction term of CEO tenure with a coastal dummy (COASTAL DMY) to find the moderating effect of coastal area firms on the association

TABLE 2 | Descriptive analysis.

See section "Appendix 1" for variable details. 
between CEO tenure and CS\&EP. Moreover, in model 3, we use CEO compensation (CEO COMP) as a dependent variable to assess the impact of a CEO's CS\&EP in their initial service years (initial service years) on their compensation package, which is equivalent to the average CS\&EP of the initial 4 years of the CEO's service period. We also use firm performance measure return on asset ROA (initial service years) as a control variable. Firm performance is a significant judgment criterion that cannot be ignored when assessing an executive's compensation contract. The rest of the control variables in model 1 are also used in the evaluation process.

\section{MAIN RESULTS AND ANALYSES}

\section{Descriptive Analysis of the Variables}

The present study uses Stata software to analyze the data. Stata is a multipurpose program able to produce statistical analyses, simulations, data management, graphics, and regression analyses. The descriptive summary of all the important variables is presented in Table 2. CS\&EP is a dependent variable in this study, having mean and median values of 38.45 and 35.08, respectively. The standard deviation value of CS\&EP is 13.27, suggesting a notable distinction in CS\&EP between the sample firms. CEO tenure (CEO TNUR) is an independent variable having mean and median values of 6.02 and 5 , respectively.

Table 2 also exhibits the mean and median values of CEO age (CEO AG) as 53.34 and 53 years, indicating that the average age of a CEO in a Chinese firm is 53 years. The mean value of CEO duality is 0.16 , meaning that $16.7 \%$ of CEOs also hold a chair position in the firm's board. The average value of CEO gender (CEO GNDR) is 0.96, indicating that $96 \%$ of our selected sample is male. Approximately $45 \%$ of the directors in our sample are independent ( $\mathrm{P}$. INDBRD). The average value of firm size (F. SIZE) is 23.26. Moreover, the mean and median values of firm age (F. AG) are 16.54 and 16 years, respectively. The mean and median values of ownership concentration (OWNR CONCN) are 59.24 and 59.340, indicating that Chinese organizations are more concentrated and monitored by the top ten shareholders. The average value of leverage (LEVG) is 0.51 . The selected sample firms are profitable ( $\mathrm{ROA}$ mean value $=6.83$ ), and approximately $56 \%$ of the sample firms' headquarters are situated in coastal areas of China (see section "Appendix 1" for an explanation of the variables.).

The correlation matrix is presented in Table 3. The correlation parameter between CS\&EP and CEO TNUR is -0.02 . The value is less than the significance level of $1 \%$, supporting hypothesis H1. Table 3 shows that multicollinearity does not exist among the selected variables. Moreover, we tested the variance inflation factors (VIF) to examine the multicollinearity issue in the given dataset. The VIF value is 3.24 , indicating that multicollinearity is not an issue in the given dataset because the VIF value is less than five (Baccouche et al., 2013).

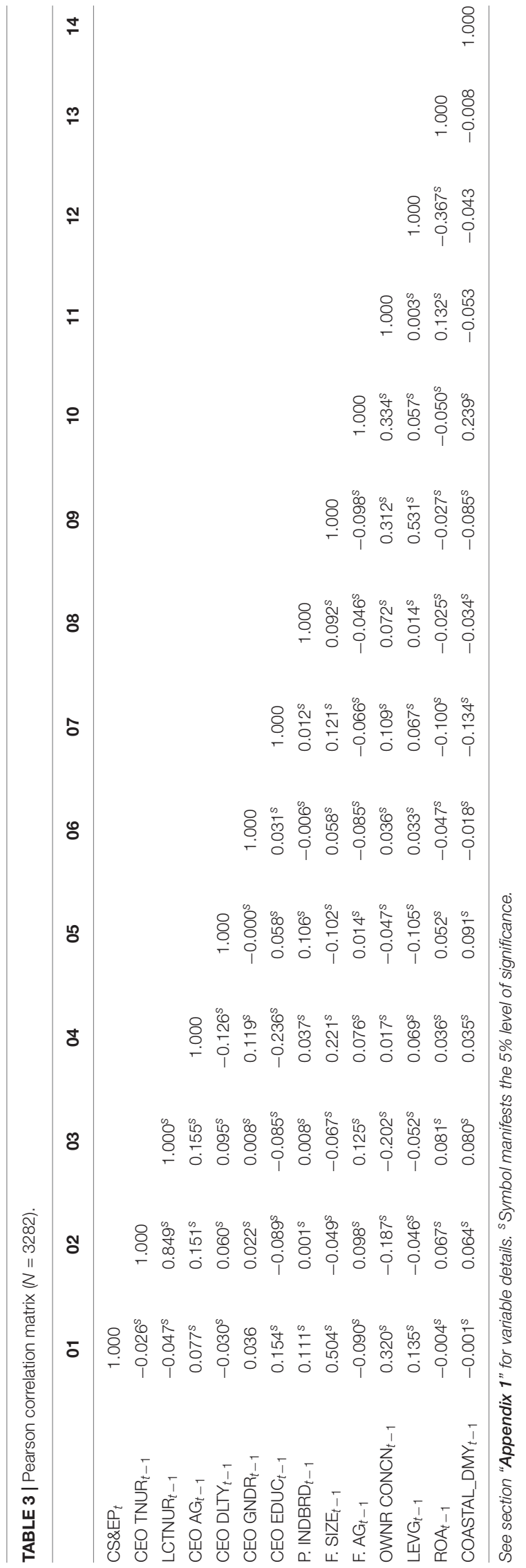




\section{Main Results}

Table 4 depicts the full-sample regression results to determine the impact of CEO tenure on CS\&EP. We can see that the parameter of CEO TNUR is negative but significant at the 1\% level (0.07), suggesting that $\mathrm{CEO}$ tenure has a negative and significant impact on the firm's CS\&EP. The regression findings show that firms' CS\&EP is more excessive in the early tenure of their CEOs than in their later tenure, which is consistent with hypothesis H1. The present study used a Hausman test to choose between a fixed or random effects model. Our test results show that the $p$-value is significant at the $1 \%$ level $\left(307.82^{* * *}\right)$, suggesting that the fixed effects model is preferable. The rest of the coefficients, i.e., ownership concentration (OWNR CONCN), firm size (F. SIZE), and firm age (F. AG), are positive and significant, consistent with the extant literature (Wang et al., 2013; McGuinness et al., 2017; Shahab et al., 2018; Shah et al., 2019; Li et al., 2020).

In this study, CEO tenure is our key variable of interest, defined as the entire number of service years an executive carries the chief executive title. However, we anticipate that tenure might not affect the firm's social practices monotonically. Thus, we modify model 1 in this study by adding longertenured CEOs LCTNUR rather than CEO TNUR. LCTNUR is a dummy variable that is equal to one if the tenure exceeds 10 years and zero otherwise (Chen and Tsang, 2017). Table 4, column (b) shows that the coefficient of LCTNUR is negative and significant (-0.60), indicating that the firm's CS\&EP decreases during the later tenure.

To further clarify the findings, we reexamine model 1 by replacing CEO TNUR with indicator variables for the initial 5 years of executive tenure (Ali and Zhang, 2015). We take Y. ONE, Y. TWO, Y. THREE, Y. FOUR, and Y. FIVE to equal one if the observation belongs to the initial 5 years of executive tenure and zero otherwise. Table 5 shows that the parameters of Y. TWO and Y. FOUR are positive and significant, having values of 0.82 and 0.93, respectively. This suggests that CS\&EP increases in the second and fourth years of an executive's tenure. The parameter estimate belonging to Y. THREE is marginally significant and positive (0.43). The parameter of Y. ONE is insignificant but also positive. The extant research has documented that executives are not effective in engaging social practices in their first year of service (Chin et al., 2013). Here, we can note that the parameter of Y. FIVE is insignificant and negative. Collectively, our results show that the CS\&EP of firms enhances in the second, third, and fourth years of a CEO's tenure; subsequently, the performance shows a decreasing trend in their later years of service.

\section{Endogeneity Test Using Two-Stage Least Squares}

We used the Two-Stage Least Squares (2SLS) technique to address the endogeneity problem. To control the impact of omitted variables, we placed an instrument variable (IV) in our model. While running the first-stage regression analysis, we took the industry average of CEO tenure in the previous year (TNUR. INDAVG) as an IV. The variable TNUR. INDAVG may affect the tenure of the CEO but did not correlate with CS\&EP. In the second stage of the regression, we deploy the predicted CEO tenure (P. CEOTNUR) derived from the regression findings of the first stage. We examine the effect of predicted CEO tenure on CS\&EP. The regression results are shown in Table 6. The parameter of $\mathrm{P}$. CEOTNUR is significant with a negative value of -0.77 , indicating that the effect of tenure on CS\&EP holds after resolving the endogeneity problem with the 2 SLS method.

\section{Coastal Areas Effect}

Table 7 presents the findings of hypothesis H2. In model 2, column (a), we interact CEO TNUR with COASTAL DMY, where COASTAL DMY is a dummy variable equal to one if the firm's headquarters is situated in a coastal area of China and zero otherwise. The coefficient of CEO TNUR*COASTAL DMY is significantly positive $(0.160)$, suggesting that the firms with head

TABLE 4 | The effect of tenure on CS\&EP.

\begin{tabular}{|c|c|c|c|c|}
\hline \multirow[t]{2}{*}{ Dependent variable $=C_{C S \& E P}$} & \multicolumn{2}{|c|}{ (a) } & \multicolumn{2}{|c|}{ (b) } \\
\hline & Parameter estimate & t. static & Parameter estimate & t. static \\
\hline CEO TNUR TI--1 $_{t}$ & $-0.076^{\star \star}$ & -2.02 & & \\
\hline LCTNUR $_{t-1}$ & & & $-0.608^{\star \star}$ & -2.01 \\
\hline $\mathrm{CEO} \mathrm{AG}_{t-1}$ & -0.0376 & -1.07 & -0.043 & -1.25 \\
\hline CEO DLTY $Y_{t-1}$ & 0.018 & 0.04 & 0.028 & 0.06 \\
\hline CEO GNDR GN-1 $_{t}$ & 0.511 & 0.40 & 0.557 & 0.43 \\
\hline P. INDBRD $_{t-1}$ & -0.003 & -0.47 & -0.003 & -0.42 \\
\hline F. SIZE $E_{t-1}$ & $1.469^{\star \star \star}$ & 2.71 & $1.452^{\star \star \star}$ & 2.68 \\
\hline $\mathrm{F} . \mathrm{AG}_{t-1}$ & $2.054^{\star \star \star}$ & 19.79 & $2.041^{* \star *}$ & 20.07 \\
\hline OWNR CONCN $\mathrm{CON}_{t-1}$ & $0.038^{\star}$ & 1.84 & $0.038^{\star}$ & 1.85 \\
\hline $\mathrm{LEVG}_{t-1}$ & -2.502 & -1.54 & -2.441 & -1.50 \\
\hline Constant & $-25.935^{\star \star}$ & -2.30 & $-25.432^{\star \star}$ & -2.25 \\
\hline Hausman check & $307.82^{\star \star \star}$ & & $319.19^{\star \star \star}$ & \\
\hline No of observations & 2,514 & & 2,514 & \\
\hline R. Square & 0.384 & & 0.384 & \\
\hline
\end{tabular}

See section "Appendix 1 " for variable details. ${ }^{*},{ }^{* *}$, and ${ }^{* * *}$ is equal to significant level at $<10,5$, and $1 \%$, respectively. 
TABLE 5 | The effect of the CEO's initial service years on CS\&EP.

\begin{tabular}{|c|c|c|}
\hline Dependent variable $=C_{C S} \& P_{t}$ & Parameter estimate & t. static \\
\hline $\mathrm{Y} . \mathrm{ONE}_{t-1}$ & 1.118 & 1.39 \\
\hline $\mathrm{Y} . \mathrm{TWO}_{t-1}$ & $0.828^{\star}$ & 1.68 \\
\hline Y. THREE $_{t-1}$ & 0.438 & 1.61 \\
\hline Y. FOUR F $_{t-1}$ & $0.937^{*}$ & 1.83 \\
\hline Y. FIVE $_{t-1}$ & -0.742 & -1.35 \\
\hline CEO DLTYt-1 & 0.019 & 0.04 \\
\hline CEO GNDR G $_{t-1}$ & 0.126 & 0.10 \\
\hline P. INDBRD $_{t-1}$ & -0.004 & -0.51 \\
\hline F. SIZE $E_{t-1}$ & $-3.664^{\star \star}$ & -2.09 \\
\hline F. $A G_{t-1}$ & $2.437^{\star \star \star}$ & 16.17 \\
\hline $\mathrm{LEVG}_{t-1}$ & -1.248 & -0.82 \\
\hline Constant & $11.414^{\star \star \star}$ & 3.49 \\
\hline Hausman check & $614.67^{\star \star \star}$ & \\
\hline No of observations & 2,514 & \\
\hline R. Square & 0.383 & \\
\hline
\end{tabular}

See section "Appendix 1" for variable details. *, **, and ${ }^{* * *}$ is equal to significant level at $<10,5$, and $1 \%$, respectively.

TABLE 6 | Resolving the endogeneity problem using 2SLS.

\begin{tabular}{|c|c|c|c|c|}
\hline \multirow[t]{4}{*}{ Dependent variable } & \multicolumn{2}{|c|}{ (a) } & \multicolumn{2}{|c|}{ (b) } \\
\hline & \multicolumn{2}{|c|}{ 1st. Stage } & \multicolumn{2}{|c|}{ 2nd. Stage } \\
\hline & \multicolumn{2}{|c|}{$=$ CEO TNUR TN--1 $_{t}$} & \multicolumn{2}{|c|}{$=C S \& E P_{t}$} \\
\hline & $\begin{array}{c}\text { Parameter } \\
\text { estimate }\end{array}$ & t. static & $\begin{array}{c}\text { Parameter } \\
\text { estimate }\end{array}$ & t. static \\
\hline P. CEOTNUR & & & $-0.772^{\star \star \star}$ & -7.03 \\
\hline TNUR. INDAVG ${ }_{t-1}$ & $0.980^{\star \star \star}$ & 33.97 & & \\
\hline CEO AG $A_{t-1}$ & $0.101^{\star \star \star}$ & 11.41 & $-0.089^{\star \star \star}$ & -2.66 \\
\hline CEO DLTYt-1 & $0.269^{\star}$ & 1.76 & 0.611 & 1.14 \\
\hline CEO GNDR t $_{t-1}$ & 0.215 & 0.68 & 0.748 & 0.62 \\
\hline P. INDBRD $_{t-1}$ & 0.001 & 0.40 & $0.262^{*}$ & 1.70 \\
\hline F. SIZE $t-1$ & $0.119^{\star \star \star}$ & 2.84 & $4.648^{\star \star \star}$ & 28.58 \\
\hline F. $A G_{t-1}$ & -0.018 & -1.53 & 0.051 & 1.12 \\
\hline OWNR CONCN $\mathrm{CN}_{t-1}$ & $-0.032^{\star \star \star}$ & -8.88 & $0.123^{\star \star \star}$ & 8.72 \\
\hline $\mathrm{LEVG}_{t-1}$ & $-0.768^{\star \star}$ & -2.29 & $-7.409^{\star \star \star}$ & -5.76 \\
\hline Constant & $-5.778^{\star \star \star}$ & -6.22 & $-74.344^{\star \star \star}$ & -21.14 \\
\hline No of observations & 2,514 & & 2,514 & \\
\hline R. Square & 0.376 & & 0.400 & \\
\hline
\end{tabular}

See section "Appendix 1" for variable details. *, **, and ${ }^{* *}$ is equal to significant level at $<10,5$, and $1 \%$, respectively.

offices in the coastal areas of China weaken the inverse effect of CEO tenure on CS\&EP, while the coefficients of CEO TNUR and COASTAL DMY are also positively significant, indicating that CS\&EP is more focused in the coastal areas of China than non-coastal ones. Our results further suggest that CEOs pay more attention to social and environmental investments in coastal areas due to the excessive pressure they face from various stakeholders. The results in column (b) are also consistent with the results in column (a). Our findings fill the gap in the limitations mentioned by Khan et al. (2020b) and provide evidence that CS\&EP varies in coastal and non-coastal areas.
TABLE 7 | CEO tenure and CS\&EP: The impact of Coastal areas.

\begin{tabular}{|c|c|c|c|c|}
\hline \multirow[t]{2}{*}{ Dependent variable $=C_{C S \& E P}$} & \multicolumn{2}{|c|}{ (a) } & \multicolumn{2}{|c|}{ (b) } \\
\hline & $\begin{array}{c}\text { Parameter } \\
\text { estimate }\end{array}$ & t. static & $\begin{array}{c}\text { Parameter } \\
\text { estimate }\end{array}$ & t. static \\
\hline CEO TNUR $R_{t-1}$ & $0.305^{\star \star \star}$ & 4.91 & & \\
\hline LCTNUR $_{t-1}$ & & & $1.804^{\star \star \star}$ & 3.40 \\
\hline CEO TNUR ${ }^{*}$ COASTAL DMY $Y_{t-1}$ & $0.160^{\star \star}$ & 2.02 & & \\
\hline LCTNUR $^{\star}$ COASTAL DMY ${ }_{t-1}$ & & & $1.678^{\star \star}$ & 2.46 \\
\hline COASTAL DMY $Y_{t-1}$ & $14.166^{\star \star \star}$ & 2.59 & $14.587^{\star \star \star}$ & 2.66 \\
\hline CEO AG $t-1$ & $0.170^{\star \star \star}$ & 3.33 & $0.225^{\star \star \star}$ & 4.51 \\
\hline CEO DLTY $t-1$ & $1.540^{\star *}$ & 2.28 & $1.399^{\star \star}$ & 2.11 \\
\hline CEO GNDR G $_{t-1}$ & $-8.473^{\star \star \star}$ & -3.58 & $-9.083^{\star * \star}$ & -3.82 \\
\hline CEO EDUC t-1 $_{t}$ & $0.838^{\star \star}$ & 1.95 & $0.999^{\star \star}$ & 2.32 \\
\hline P. INDBRD $_{t-1}$ & $0.0487^{\star \star \star}$ & 4.84 & $0.050^{\star \star \star}$ & 4.99 \\
\hline OWNR CONCN $\mathrm{CON}_{t-1}$ & $-0.067^{\star \star \star}$ & -2.37 & $-0.072^{\star \star \star}$ & -2.54 \\
\hline $\mathrm{LEVG}_{t-1}$ & $4.077^{\star \star}$ & 1.97 & $4.247^{\star \star}$ & 2.04 \\
\hline Constant & $25.866^{\star \star \star}$ & 4.95 & $24.513^{\star \star \star}$ & 4.67 \\
\hline Hausman check & $92,71^{\star \star \star}$ & & $90.46^{\star \star \star}$ & \\
\hline No of observations & 1,968 & & 1,968 & \\
\hline R. Square & 0.144 & & 0.131 & \\
\hline
\end{tabular}

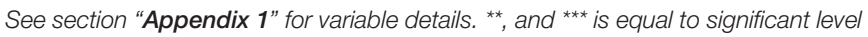
at $<5$, and $1 \%$, respectively.

TABLE 8 | The impact of CS\&EP on CEO Compensation.

\begin{tabular}{|c|c|c|}
\hline Dependent variable $=\mathrm{CEO} . \mathrm{COMP}_{t}$ & Parameter estimate & t. static \\
\hline CS\&EP ${ }_{t}$ & $0.255^{\star}$ & 1.67 \\
\hline $\mathrm{ROA}_{t}$ & 0.000 & 0.01 \\
\hline CEO AG $A_{t-1}$ & $0.014^{\star}$ & 1.84 \\
\hline CEO DLTY $_{t-1}$ & 0.063 & 0.53 \\
\hline CEO GNDR G $_{t-1}$ & -0.153 & -0.52 \\
\hline P. INDBRD $_{t-1}$ & $-0.009^{\star \star \star}$ & -5.21 \\
\hline OWNR CONCN CON-1 $_{t}$ & -0.002 & -0.43 \\
\hline $\mathrm{LEVG}_{t-1}$ & $-0.880^{* \star \star}$ & -2.38 \\
\hline Constant & $11.812^{\star \star \star}$ & 14.82 \\
\hline Hausman Check & $29.32^{\star \star \star}$ & \\
\hline No of observations & 2,349 & \\
\hline R. Square & 0.02 & \\
\hline
\end{tabular}

See section "Appendix 1" for variable details. *, and *** is equal to significant level at $<10$, and $1 \%$, respectively.

\section{Value-Added Hypothesis}

Table 8 shows the results of model 3. We asked an interesting question that had not been addressed in the extant research regarding whether CEOs could be rewarded for their social and environmental commitment in their initial service years. The parameter of CS\&EP is positively significant (0.25), indicating that the increase in a CEO's CS\&EP in their early tenure increases their total compensation, which is consistent with hypothesis H3. In other words, higher CS\&EP is associated with improved shareholder wealth; therefore, rewarding CEOs with compensation packages ultimately reduces their career-related concerns. Our results align with Jian and Lee's (2015) value-creation hypothesis, 
indicating that the increase in CS\&EP is positively linked with CEO compensation.

\section{CONCLUDING REMARKS}

Due to the growth in stakeholders' expectations and institutional changes, China-as the world's second largest emerging economy-provides an attractive market for research. It enables us to investigate how CEO tenure influences firms' CS\&EP in coastal and non-coastal areas of China. The growing interest of scholars in the field of social and environmental practices in the Chinese context means that many studies have examined the association between executive attributes and firms' economic, social, and environmental performance ( $\mathrm{Lu}$ et al., 2015; McGuinness et al., 2017; Shahab et al., 2018). By extending beyond this line of research, we filled a gap by empirically scrutinizing the effects of CEO tenure on CS\&EP in coastal and non-coastal areas of China. Moreover, we have contributed to the existing literature by providing evidence that a CEO's CS\&EP during their initial tenure may increase their compensation package. We used data of listed firms for the period of 2009 to 2015 and showed that CEOs with shorter service tenures (i.e., CEOs in their initial service years) are more likely to be involved in CS\&EP than CEOs with longer service tenures. Our findings also demonstrate an interesting outcome, showing that CS\&EP is more concentrated in the coastal areas of China. Our study provides evidence that the inverse effect of CEO tenure on CS\&EP is weaker in coastal areas. Finally, we show that CEOs' CS\&EP in their initial service years increases their compensation packages by reducing their career-related concerns.

The present study has several implications for business leaders and policymakers as they develop strategies to make organizations more responsible for their social and environmental goals. Many researchers have documented a significant association between social practices and firm financial performance. Therefore, all the monitoring authorities (like governments and boards of directors) have considered the importance of social and environmental practices. Therefore, CEOs should be urged to focus more on CS\&EP. Accordingly, many firms have taken serious steps to factor CS\&EP into their assessments of CEO performance. In addition, our study provides evidence that $\mathrm{CEO}$ tenure is an essential determinant that could influence CS\&EP. Moreover, governments and firms' boards should set up CEO tenure-related benefits (i.e., increase CEOs' compensation packages) to encourage CEOs to engage in social and environmental practices that could be equally beneficial for both shareholders and stakeholders.

\section{REFERENCES}

Ali, A., and Zhang, W. (2015). CEO tenure and earnings management. J. Account. Econ. 59, 60-79. doi: 10.1016/j.jacceco.2014.11.004

Baccouche, S., Hadriche, M., and Omri, A. (2013). The impact of audit committee multiple-directorships on earnings management: evidence from france. J. Appl. Bus. Res. 29, 1333-1342. doi: 10.19030/jabr.v29i5. 8017
Executives' policies regarding employee protection could also be helpful in reducing the spread of COVID-19 by implementing the guidance (i.e., social distancing) provided by the World Health Organization. Moreover, this study is also useful for the stakeholders involved in CS\&EP evaluation and sustainable development, as well as mutual fund managers, to understand regional differences. By using our findings, these stakeholders can draw meaningful conclusions.

The present study could be extended to future research. We chose a sample of firms listed on the Shenzhen and Shanghai stock markets to explore the benefits related to social and environmental performance; thus, future studies could extend this line of research by investigating the impact of CEO tenure on social, economic, and environmental disclosure practices. Second, we recommend examining the moderating role of institutional investors and financial analysts on the link between CEO tenure and CS\&EP. Third, since we used a sample of Chinese listed firms, our results may not be generalized to different territories. Future research could improve on this study by investigating how CEOs use social activities to signal their capabilities in different scenarios.

\section{DATA AVAILABILITY STATEMENT}

The raw data supporting the conclusions of this article will be made available by the authors, without undue reservation.

\section{AUTHOR CONTRIBUTIONS}

TK has contributed to the definition of research objectives, developing models, hypotheses, data analysis plan, article writing, revision and proofreading, and final approval. GB has contributed by developing models, hypothesis revision, and proofreading. ZF has contributed in research objectives, data analysis, and results' interpretation. SQ has contributed in drafting the work, validation of results, and revision. ZK and WK have contributed to data collection, analysis, drawing limitations, future directions, and the conclusion of the study. All authors contributed to the article and approved the submitted version.

\section{ACKNOWLEDGMENTS}

We are very thankful to the respected editor and reviewers for their insightful comments and suggestions which helped us to improve the overall impression of this study.
Benabou, R., and Tirole, J. (2010). Individual and corporate social responsibility. Economica 77, 1-19. doi: 10.1002/9781118106686.ch1

Berrone, P., and Gomez-mejia, L. R. (2009). Environmental performance and executive com-pensation an integrated agency-institutional perspective. Acad. Manag. J. 52, 103-126. doi: 10.5465/amj.2009.36461950

Borghesi, R., Houston, J. F., and Naranjo, A. (2014). Corporate socially responsible investment CEO altruism, reputation, and shareholder interests. J. Corp. Finance 26, 164-181. doi: 10.1016/j.jcorpfin.2014.03.008 
Callan, S. J., and Thomas, J. M. (2011). Executive compensation, corporate social responsibili-ty, and corporate financial performance: a multi-equation framework. Corp. Soc. Responsibil. Environ. Manag. 18, 332-351. doi: 10.1002/ csr.249

Cao, W., and Wong, M. H. (2007). Current status of coastal zone issues and management in China: a review. Environ. Int. 33, 985-992. doi: 10.1016/j. envint.2007.04.009

Chen, L., and Tsang, A. (2017). CEO Tenure and Corporate Social Responsibility (CSR) Reporting. Fairfax: George Mason Univerisity, 1-51.

Chen, S., and Pearson, S. (2015). Managing China's coastal environment: using a legal and re-gulatory perspective. Intl. J. Environ. Sci. Dev. 6, 225-230. doi: 10.7763/ijesd.2015.v6.595

Chin, M. K., Hambrick, D. C., and Treviño, L. K. (2013). Political ideologies of CEOs. Adm. Sci. Q. 58, 197-232.

Chiu, S. C., and Sharfman, M. (2016). Corporate social irresponsibility and executive successi-on: an empirical examination. J. Bus. Ethics 149, 707-723. doi: 10.1007/s10551-016-3089-7

Cochran, P. L., and Wood, R. A. (1984). Corporate social responsibility and financial performance. Acad. Manag. J. 27, 42-56.

Conyon, M., and He, L. (2012). CEO pay and corporate governance in China. corporate gover-nance. Intl. Rev. 20, 575-592. doi: 10.1111/j.1467-8683.2012. 00935.x

Coombs, J. E., and Gilley, K. M. (2005). Stakeholder management as a predictor of CEO compe-nsation main effects and interactions with financial performance. Strateg. Manag. J. 26, 827-827. doi: 10.1002/smj.476

Cornell, B., and Shapiro, A. C. (1987). Corporate stakeholders and corporate finance. Financ. Manag. 16, 5-14. doi: 10.2307/3665543

Dam, L., and Scholtens, B. (2013). Ownership concentration and CSR policy of European mul-tional enterprises. J. Bus. Ethics 118, 117-126. doi: 10.1007/ s10551-012-1574- 1

Deckop, J. R., Merriman, K., and Shurti, G. (2006). The effects of CEO pay structure on corpo-rate social performance. J. Manag. 32, 329-342. doi: 10. $1177 / 0149206305280113$

Elkington, J. (1994). Towards the sustainable corporation: win-win-win business strategies for sustainable development. Calif. Manag. Rev. 36, 90-100. doi: $10.2307 / 41165746$

Fama, E. F. (1980). Agency problems and the theory of the firm. J. Polit. Econ. 88, 288-307. doi: 10.1086/260866

Fernández-Guadaño, J., and Sarria-Pedroza, J. H. (2018). Impact of corporate social responsib- bility on value creation from a stakeholder perspective. Sustainability 10:1. doi: 10.3390/su10062062

Fleisher, B. M., and Chen, J. (1997). The coast-noncoast income gap, productivity, and region-al economic policy in China. J. Comp. Econ. 25, 220-236. doi: 10.1006/jcec.1997.1462

Friede, G., Busch, T., and Bassen, A. (2015). ESG and financial performance: aggregated evi-dence from more than 2000 empirical studies. J. Sustainable Finance Investment 5, 210-233. doi: 10.1080/20430795.2015.1118917

Gao, Y., Wu, J., and Hafsi, T. (2017). The inverted U-shaped relationship between corporate philanthropy and spending on research and development: a case of complementarity and competition moderated by firm size and visibility. Corp. Soc. Responsibil. Environ. Manag. 24, 465-477. doi: 10.1002/csr. 1420

Gibbons, R., and Murphy, K. J. (1992). Optimal incentive contracts in the presence of career concerns: theory and evidence. J. Polit. Econ. 100, 468-505. doi: $10.1086 / 261826$

Greening, D. W., and Turban, D. B. (2000). Corporate social performance as a competitive advantage in attracting a quality workforce. Bus. Soc. 39, 254-280. doi: $10.1177 / 000765030003900302$

Hambrick, D. C., and Mason, P. A. (1984). Upper echelons: the organization as a reflection of its top managers. Acad. Manag. Rev. 9, 193-206. doi: 10.2307/ 258434

Hermalin, B. B. E., and Weisbach, M. S. (1998). American economic association endogenous-ly chosen boards of directors and their monitoring of the CEO. Am. Econ. Rev. 88, 96-118. doi: 10.2307/116820

Hill, C. W. L., and Jones, T. M. (1992). Stakeholder-agency theory. J. Manag. Studies. 29, 131-154. doi: 10.1111/j.1467-6486.1992.tb00657.x

Holmstrom, B. (1982). Moral hazard in teams. Bell J. Econ. 13, 324-340. doi: $10.2307 / 3003457$
Hong, B., Li, Z., and Minor, D. (2016). Corporate governance and executive compensation for corporate social responsibility. J. Bus. Ethics 136, 199-213.

Hong, H., and Xue, X. (2006). Building up a training base for integrated coastal management- through partnerships in Xiamen. Ocean Coast. Manag. 49, 685695. doi: 10.1016/j.ocecoaman.2006.06.004

Hu, N., Hao, Q., Liu, L., and Yao, L. J. (2015). Managerial tenure and earnings management. Intl. J. Account. Inform. Manag. 23, 42-59. doi: 10.1108/ijaim04-2014-0025

Hu, Y., Chen, S., Shao, Y., and Gao, S. (2018). CSR and firm value: evidence from China. Sustainability 10:1. doi: 10.3390/su10124597

Jian, M., and Lee, K.-W. (2015). CEO compensation and corporate social responsibility. J. Multinatlional Financ. Manag. 29, 46-65. doi: 10.1016/j. mulfin.2014.11.004

Johnson, R. A., and Greening, D. W. (1999). The effects of corporate governance and institutio-nal ownership types on corporate social performance. Acad. Manag. J. 42, 564-576. doi: 10.5465/256977

Karim, K., Lee, E., and Suh, S. (2018). Corporate social responsibility and CEO compensation structure. Adv. Account. 40, 27-41. doi: 10.1016/j.adiac.2017.11. 002

Khan, F. U., Zhang, J., Usman, M., Badulescu, A., and Sial, M. S. (2019). Ownership reduction in state-owned enterprises and corporate social res-ponsibility: perspective from secondary privatization in China. Sustainability 11:1008. doi: $10.3390 /$ su1 1041008

Khan, T. M., Gang, B., Fareed, Z., and Khan, A. (2020a). How does CEO tenure affect corporate social and environmental disclosures in China? moderating role of information intermediaries and independent board. Environ. Sci. Pollut. Res. doi: 10.1007/s11356-020-11315-9 Online head of print.

Khan, T. M., Gang, B., Fareed, Z., and Yasmeen, R. (2020b). The impact of CEO tenure on corporate social and environmental performance: an emerging country's analysis. Environ. Sci. Pollut. Res. 27, 19314-19326. doi: 10.1007/ s11356-020-08468-y

Kohlberg, L. (1969). "Stage and sequence: the cognitive developmental approach to socializa-tion," in Handbook of Socialization Theory and Research, ed. D. Goslin (Chicago: Rand McNally).

Lahouel, B., Peretti, J.-M., and Autissier, D. (2014). Stakeholder power and corporate social performance. Corp. Governance Intl. J. Bus. Soc. 14, 363-381. doi: $10.1108 / \mathrm{cg}-07-2012-0056$

Laszlo, C., and Cescau, P. (2017). Sustainable Value: How the World's Leading Companies are Doing Good. Abingdon: Routledge.

Li, H., Hang, Y., Shah, S. G. M., Akram, A., and Ozturk, I. (2020). Demonstrating the impact of cognitive CEO on Firms' performance and CSR Activity. Front. Psychol. 11:278.

Li, K., Khalili, N. R., and Cheng, W. (2019). Corporate social responsibility practices in Chi- na trends, context, and impact on company performance. Sustainability 11, 2-19.

Liu, F., and Zhang, L. (2017). Executive turnover in China's state-owned enterprises: government-oriented or market-oriented? China J. Account. Res. 11, 129-149. doi: 10.1016/j.cjar.2016.12.003

Lu, Y., Abeysekera, I., and Cortese, C. (2015). Corporate social responsibility reporting quality, board characteristics, and corporate social reputation: evidence from China. Pacific Account. Rev. 27, 95-118. doi: 10.1108/par-102012-0053

Lys, T., Naughton, J. P., and Wang, C. (2015). Signalling through corporate accountability reporting. J. Account. Econ. 60, 56-72. doi: 10.1016/j.jacceco. 2015.03.001

Manner, M. H. (2010). The impact of CEO characteristics on corporate social performance. J. Bus. Ethics 93, 53-72. doi: 10.1007/s10551-0100626-7

Marquis, C., and Qian, C. (2013). Corporate social responsibility reporting in china: symbol or substance? Organ. Sci. 25, 127-148. doi: 10.1287/orsc.2013. 0837

McGuinness, P. B., Vieito, J. P., and Wang, M. (2017). The role of board gender and foreign ownership in the CSR performance of Chinese listed firms. J. Corp. Finance 42, 75-99. doi: 10.1016/j.jcorpfin.2016.11.001

National People's Congress [NPC] (2005). The Company Law of the People's Republic of China. Beijing: NPC.

Navarro, P. (1988). Why do corporations give to charity? J. Bus. 61, 65-93. doi: $10.1086 / 296420$ 
Oh, W. Y., Chang, Y. K., and Cheng, Z. (2014). When CEO career horizon problems matter for corporate social responsibility: the moderating roles of industry-level discretion and blockholder ownership. J. Bus. Ethics 133, 279291. doi: 10.1007/s10551-014-2397-z

Ortas, E., Álvarez, I., and Zubeltzu, E. (2017). Firms' board independence and corporate social performance: a meta-analysis. Sustainability 9:1006. doi: 10. 3390/su9061006

Palmer, H. J. (2012). Corporate Social Responsibility and Financial Performance: Does it Pay to be Good?. CMC Senior Theses. Paper 529. https://scholarship. claremont.edu/cmc_theses/529

Pan, Y., Wang, T. Y., and Weisbach, M. S. (2016). CEO investment cycles. Rev. Financ. Stud. 29, 2955-2999. doi: 10.1093/rfs/hhw033

Price, J. M., and Sun, W. (2017). Doing good and doing bad: the impact of corporate social responsibility and irresponsibility on firm performance. J. Bus. Res. 82-97. doi: 10.1016/j.jbusres.2017.07.007

Purdy, M. J., and Chang, X. (2014). Do clusters influence productivity in China's software industry. Theor. Econ. Lett. 04, 26-33. doi: 10.4236/tel.2014.410

Qin, Q., Zhu, L., Ghulam, A., Li, Z., and Nan, P. (2008). Satellite monitoring of spatiotemporal dynamics of China's coastal zone eco-environments: preliminary analysis on the relationship between the environment, climate change, and human behavior. Environ. Geol. 55, 1687-1698. doi: 10.1007/ s00254-007-1120-0

Russo, M. V., and Harrison, N. S. (2005). Organizational design and environmental performanceclues from the electronics industry. Acad. Manag. J. 48, 582-593. doi: 10.5465/amj.2005.17843939

Sarfraz, M., Ozturk, I., Shah, S. G. M., and Maqbool, A. (2020a). Contemplating the impact of the moderators agency cost and number of supervisors on corporate sustainability Under the aegis of a Cognitive CEO. Front. Psychol. 11:965.

Sarfraz, M., Shah, S. G. M., Fareed, Z., and Shahzad, F. (2020b). Demonstrating the interconnection of hierarchical order disturbances in CEO succession with corporate social responsibility and environmental sustainability. Corp. Soc. Responsibil. Environ. Manag. 27, 2956-2971. doi: 10.1002/csr. 2014

Sen, S., and Bhattacharya, C. B. (2001). Does doing good always lead to doing better? customer reactions to corporate social responsibility. J. Mark. Res. 38, 225-243. doi: 10.1509/jmkr.38.2.225.18838

Shah, S. G. M., Tang, M., Sarfraz, M., and Fareed, Z. (2019). The aftermath of CEO successionvia hierarchical jumps on firm performance and agency cost:evidence from Chinese firms. Appl. Econ. Lett. 26, 1744-1748. doi: 10.1080/13504851. 2019.1593932

Shahab, Y., Ntim, C. G., Chengang, Y., Ullah, F., and Fosu, S. (2018). Environmental policy, environmental performance, and financial distress in China: do top management team characteristics matter? Bus. Strategy Environ. 27, 1635-1652. doi: 10.1002/bse.2229

Sharma, S., and Vredenburg, H. (1998). Proactive corporate environmental strategy and the development of competitively valuable organizational capabilities. Strateg. Manag. J. 19, 729-753. doi: 10.1002/(sici)1097-0266(199808)19:8<729:: aid-smj967>3.0.co;2-4

Sial, M. S., Chunmei, Z., Khan, T., and Nguyen, V. K. (2018). Corporate social responsibility, firm performance and the moderating effect of earnings management in Chinese firms. Asia Pacific J. Bus. Adm. 10, 184-199. doi: 10.1108/apjba-03-2018-0051

State Council of the PRC (1992). Law of the People's Republic of China on the Territorial Sea and the Contiguous Zone. Available online at: http www.zhb.gov.cn/english/law_detail.php3?id=32 (accessed at February 25, 1992).
State Council of the PRC (1998). Law on the Exclusive Economic Zone and the Continental Shelf of the People's Republic of China. Available online at: http: //www.fmcoprc.gov.hk/eng/syzx/tyflsw/t944939.htm

State Council of the PRC (2001). Law of the People's Republic of China on the use and management of Sea areas (ZhonghuaRenmin Gongheguo Haiyu Shiyong Guanli $\mathrm{Fa}$ ). Beijing: Haiyang chubanshe.

Su, W., Peng, M. W., Tan, W., and Cheung, Y. L. (2016). The signalling effect of corporate social responsibility in emerging economies. J. Bus. Ethics 134, 479-491.

Sun, C., Zhang, K., Zou, W., Li, B., and Qin, X. (2015). Assessment and evolution of the sustainable development ability of human-ocean systems in coastal regions of China. Sustainability 7, 10399-10427. doi: 10.3390/su70810399

Thia-Eng, C. (1993). Essential elements of integrated coastal zone management. Ocean Coast. Manag. 21, 81-108. doi: 10.1016/0964-5691(93)90021-p

Walker, L. J., and Frimer, J. A. (2015). Developmental trajectories of agency and communion in moral motivation. Merrill Palmer Q. 61, 412-439. doi: 10.13110/ merrpalmquar1982.61.3.0412

Wang, J., Song, L., and Yao, S. (2013). The determinants of corporate social responsibility dis closure: evidence from China. J. Appl. Bus. Res. 29, 18331847.

Wang, S., Sun, C., Li, X., and Zou, W. (2016). Sustainable development in China's coastal area: based on the driver- pressure-state- welfare- response framework and the data envelopment analysis model. Sustainability 8, 2-19.

Wang, Y. (1992). “Coastal Management in China”. in International Conference on Ocean Management in Global Change, ed. P. Fabbri (London: Elsevier Applied Science), 469-479.

Wood, D. J. (1991). Corporate social performance revisited. Acad. Manag. Rev. 16, 691-718. doi: 10.2307/258977

Wu, X. Q., Gao, M., Wang, D., Wang, Y., Lu, Q. S., and Zhang, Z. D. (2012). Framework and practice of integrated coastal zone management in shandong province, China. Ocean Coast. Manag. 69, 58-67. doi: 10.1016/j.ocecoaman. 2012.07.030

Xiong, B., Lu, W., Skitmore, Y., Chau, K. W., and Ye, M. (2016). Virtuous nexus between corporate social performance and financial performance: a study of construction enterprises in China. J. Clean. Prod. 129:233. doi: 10.1016/j.jclepro. 2016.04.078

Xue, X., Hong, H., and Charles, A. T. (2004). Cumulative environmental impacts and integrat-ed coastal management: the case of Xiamen. China J. Environ. Manage. 71, 271-283. doi: 10.1016/j.jenvman.2004.03.006

Ying, G. F., Yu, Z. H., and Cm, S. X. (2006). Guide to CSR. Beijing: Enterprise Management Publishing house. In Chinese.

Zhuang, Y., Chang, X., and Lee, Y. (2018). Board composition and corporate social responsibility performance: evidence from Chinese public firms. Sustainability 10:2752. doi: 10.3390/su10082752

Conflict of Interest: The authors declare that the research was conducted in the absence of any commercial or financial relationships that could be construed as a potential conflict of interest.

Copyright (c) 2021 Khan, Bai, Fareed, Quresh, Khalid and Khan. This is an openaccess article distributed under the terms of the Creative Commons Attribution License (CC BY). The use, distribution or reproduction in other forums is permitted, provided the original author(s) and the copyright owner(s) are credited and that the original publication in this journal is cited, in accordance with accepted academic practice. No use, distribution or reproduction is permitted which does not comply with these terms. 


\section{APPENDIX}

APPENDIX 1 | Detail explanation of variables.

\begin{tabular}{|c|c|}
\hline Symbol & Detail \\
\hline \multicolumn{2}{|l|}{ D.V: } \\
\hline CS\&EP $t$ & Corporate social and environmental performance is predicted by the Rankins dataset ratings from 1 to 100 , for a particular firm in a certain year. \\
\hline \multicolumn{2}{|l|}{ I.V: } \\
\hline CEO AGt -1 & CEO age is defined as the age of the firm's CEO in the previous year. \\
\hline CEO DLTY $t_{t-1}$ & $\begin{array}{l}\text { CEO duality is an Indicator variable = one if the firm CEO has a dual role, such as CEO and the board chairmanship in a previous year, and zero } \\
\text { otherwise. }\end{array}$ \\
\hline $\begin{array}{l}\text { CEO GNDR } \text { GN-1 }_{t-1} \\
\text { CEO EDUC }\end{array}$ & $\begin{array}{l}\text { CEO gender is an indicator variable that is equal to one if the firm CEO is a male in a year of T-1, and zero otherwise. CEO education is an } \\
\text { indicator variable = one if the CEO has a primary education, } 2 \text { for secondary education, } 3 \text { for master's degree holders, and } 4 \text { for Ph.D. degree } \\
\text { holders in the previous year, and zero otherwise }\end{array}$ \\
\hline P. INDBRD IN-1 $_{t}$ & The percentage of an independent board of directors is predicted by calculating the\% of the firm independent board in the previous year. \\
\hline OWNR CONCN ${ }_{t-1}$ & $\begin{array}{l}\text { Firm ownership-concentration is calculated by taking the sum of the ratio of all the shares owned by the ten large shareholders in the previous } \\
\text { year. }\end{array}$ \\
\hline F. SIZE $t-1$ & Firm size is calculated by proceeding the natural logarithm of the total assets of a firm in the previous year. \\
\hline F. $A G_{t-1}$ & The age of a firm is determined as the listing age of the firm in the previous year. \\
\hline $\mathrm{ROA}_{t-1}$ & Firm return on asset is calculated by the net income divided by total assets in the previous year. \\
\hline COASTAL DMY $t-1$ & $\begin{array}{l}\text { Coastal dummy is an indicator variable which is equal to one if a firm headquarter is situated in coastal areas of China in a previous year, and } \\
\text { zero otherwise. }\end{array}$ \\
\hline $\mathrm{LEVG}_{t-1}$ & The leverage of a firm in a previous year is calculated by dividing total debts on total assets. \\
\hline Y. ONE $t-1$ & Year one is an indicator variable which is equal to one if the observation pertains to the first service year of CEO tenure, and zero otherwise. \\
\hline Y. TWO $t-1$ & Year two is an indicator variable which is equal to two if the observation pertains to the second service year of CEO tenure, and zero otherwise. \\
\hline Y. THREE $t-1$ & Year three is an indicator variable which is equal to three if the observation pertains to the third service year of CEO tenure, and zero otherwise. \\
\hline Y. FOUR $t_{t-1}$ & Year four is an indicator variable which is equal to four if the observation pertains to the fourth service year of CEO tenure, and zero otherwise. \\
\hline Y. $\mathrm{FIVE}_{t-1}$ & Year five is an indicator variable which is equal to five if the observation pertains to the fifth service year of CEO tenure, and zero otherwise. \\
\hline
\end{tabular}

